\title{
Allometric Equations for Estimating Root Systems of Mizunara Oak (Quercus crispula) in Secondary Forests
}

\author{
Guridno Bintar Saputro*, Satoshi Tatsuhara* and Hideo Miguchi*
}

\begin{abstract}
Root biomass can represent a significant proportion of the total ecosystem biomass, although the difficulty in extracting the roots is often a limiting factor when estimating the belowground biomass. The objective of this study is to create equations to estimate the root variables from other tree variables for mizunara oak (Quercus crispula BLUME) in broad-leaved secondary forests. First, experimental plots were established in secondary forests dominated by mizunara oak and sample oak trees were felled just outside the plots. The biomass of each tree organ was measured and other root variables such as root length, area and volume were also measured. Then, allocation of the four root variables by root diameter classes was described. Regression equations by power function were created between the four root variables and root diameter to estimate the missing root parts by root diameter classes and for the total root system. Root variables for missing parts were estimated from the diameter of broken root ends with regression equations between the four root variables and root diameter for total root system. Finally, allometric regressions between root variables and other tree variables were analyzed both by root diameter classes and for the total root system. Diameter at beast height (DBH) proved to be a good predictor of root variables for different root classes and for the total root system. Diameter at stump height (DSH) can be a useful estimator if branching starts at DBH as it also shows high correlation with root systems.

Keywords: missing root, root area, root biomass, root length, root volume
\end{abstract}

\section{INTRODUCTION}

Forests play an important role in regional and global carbon cycles because they store large quantities of carbon in vegetation and soil, exchange carbon with the atmosphere through photosynthesis and respiration, are sources of atmospheric carbon when they are disturbed by human or natural causes, become atmospheric carbon sinks during regrowth after disturbance, and can be managed to sequester or conserve significant quantities of carbon on the land (BRown et al., 1996). With a changing global climate, the role forests play in the uptake and release of carbon may alter. Because of their importance in the global carbon cycle, there is an increasing need to improve the accuracy of estimates of the amount of carbon the forests contain (BRown et al., 1999). Forest biomass that represents the potential amount of carbon is a useful measure for assessing changes in forest structure and for comparing structural and functional attributes of forest

\footnotetext{
* Faculty of Agriculture, Niigata University, Niigata, 950-2181 Japan
}

ecosystems across a wide range of environmental conditions (BRown et al., 1999). The biomass is composed of aboveground and belowground components. While aboveground tree biomass is often surveyed, information on belowground biomass is scarce.

Since root biomass can represent a significant proportion of the total ecosystem biomass (BöHM, 1979), and since a large proportion of annual photosynthetic production is allocated to the belowground biomass component, some methods need to be developed for estimating root biomass and production in the model (KuRz et al., 1996). Root area, the area of root surface, has seldom been determined in ecological research, although this parameter seems to be one of the best in experiments on water or nutrient uptake (BöHM, 1979). Because it is difficult to classify roots in the same way as to classify the aboveground parts, KARIZUMI (1974a) attempted to classify roots mechanically into six parts and BöHM (1979) reported that the common practice of dividing tree roots into classes with different diameters is on aid to obtain information on the amount of fine, small, medium, and large roots in a root system. Furthermore, VOGT (1989) suggested that root systems could be divided into several diameter classes based on their function in the support, storage, transport and uptake 
for field monitoring purposes. BöHM (1979) gave details of methods for studying roots. The roots $<0.2 \mathrm{~cm}$ in diameter are usually called fine roots and those $0.2-0.5 \mathrm{~cm}$ are called small roots (BöHM, 1979; KARIZUMI, 1974a). The primary (parent) root and primary laterals are the major structural supports of the tree (VoGT, 1989).

The extraction of roots is a difficult and time-consuming process that can be a limiting factor when estimating the belowground biomass. Regression equations of root systems based on calculation from easily observable measures such as diameter at beast height (DBH) (KonOPKA et al., 2000; TERMIKAELIAN and KoRZUKHIN, 1997; DrEXHAGE and COLIN, 2001; SANTANTONIO et al., 1977) might be useful as a simple input variable for growth models and carbon storage assessment. This relationship is based on the hypothesis that the growth of structural roots depends on stem diameter and that the aboveand below-stump development of trees maintains an allometric balance (LACOINTE, 2000). SANTANTONIO et al. (1977) compiled allometric regressions of root biomass on DBH for a large number of tree species. Such relationships might be very useful for predicting root system biomass as they rely on easily obtainable above-stump parameters (BARTELINK, 1998; Drexhage and Gruber, 1999; Millikin and Bledsoe, 1999; Le GoFF and OTTORINI, 2001). Regression equations of root biomass on DBH derived from other studies might be useful for applications in forestry and as a simple variable for growth models (Drexhage and Colin, 2001 and Ter-MiKaelian and KorzUKHIN, 1997). However, the fundamental question is whether allometric equations constructed for a stand growing under certain conditions are suitable also for stands in other conditions (KONOPKA et al., 2000; FuLTS, 2001).

The objective of this study is to create equations between root variables and other tree variables in order to estimate carbon storage and uptake by growth of tree biomass in broadleaved secondary forests or to estimate root variables in growth models for broad-leaved secondary forests. The subject of this study was a secondary forest dominated by mizunara oak (Quercus crispula BLUME). Not only root biomass but also root length, area and volume were analyzed as root variables. Roots were classified into root diameter classes and the four root variables were analyzed not only for total root systems but also by root diameter classes. Allometric regressions between root variables and other tree variables were analyzed after missing root parts were estimated.

\section{STUDY SITE AND METHODOLOGY}

\section{Study Site}

The study was conducted inside and outside of Niigata University Forest in Sado Island (hereafter called Sado Forest) located in the northern part of Sado Island (Latitude $38^{\circ} 12^{\prime} \mathrm{N}$; Longitude $138^{\circ} 26^{\prime} \mathrm{E}$ ) (Fig. 1). Altitude ranged from $250 \mathrm{~m}$ $970 \mathrm{~m}$ above sea level. According to weather survey point

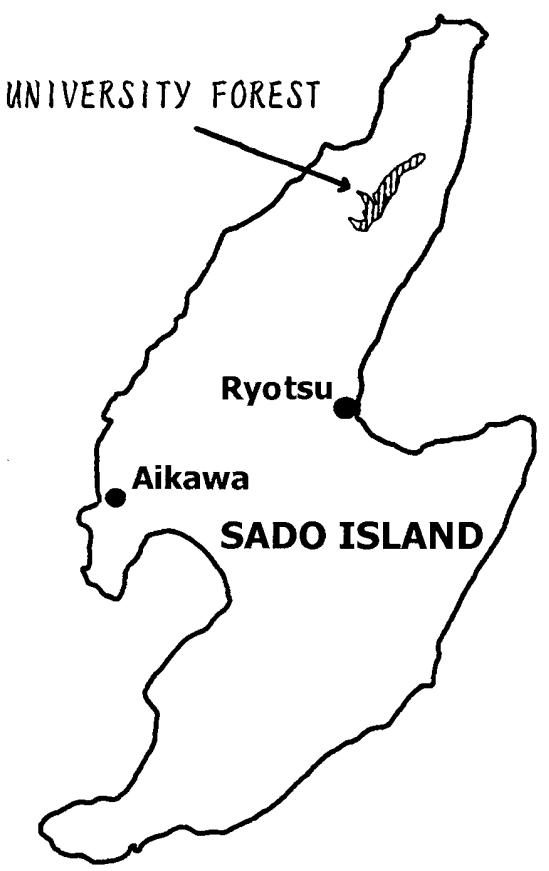

Fig. 1 Location of the study site

installed in Sado Forest, the mean annual temperature was $8.9^{\circ} \mathrm{C}$ and the mean annual precipitation was $1,312 \mathrm{~mm}$. This study site was located in the cool-temperate zone of Japan. The topography is mountainous and the parent material is andesite and basalt. The site is basically covered with a secondary forest consisting of deciduous broad-leaved trees, such as mizunara oak, konara oak (Quercus serrata MURRAY), maple species, and wingnut (Pterocarya rhoifolia SIEB. et ZUCC.). Whereas sugi (Cryptomeria japonica D. Don) grows mainly in a region of 700 or more above sea level, hiba arbour-vitae (Thujopsis dolabrata SIEB. et ZuCC.) grows in a region of $600 \mathrm{~m}$ or less.

\section{Ground Investigation}

By considering the distribution of mizunara oak, experimental plots, Plots 1 to 4, were established in Sado Forest (TATSUHARA et al., 2002) and Plot 3 was selected from the four plots for this study. Moreover, Plot 5 was set up outside Sado Forest. A summary of these plots is shown in Table 1. Standing trees with girth at breast height of $15 \mathrm{~cm}$ or more in each plot were measured.

According to the record on each tree, four or more sample trees outside the plot were selected in order to cover the whole range of diameter. In other words, dominant, codominant, intermediate, and suppressed tree should be represented so that stand estimation might not be overestimated. In Plot 5 , we chose mizunara oak with the mean DBH and subtracted or added variance of DBH ( $\sigma$ or 
Table 1 Summary of Plot 3 and Plot 5

\begin{tabular}{|c|c|c|c|c|c|c|}
\hline \multirow[t]{2}{*}{ Plot } & \multicolumn{3}{|c|}{3} & \multicolumn{3}{|c|}{5} \\
\hline & Total & Broad-leaf & Conifer & Total & Broad-leaf & Conifer \\
\hline Altitude (m) & 555 & & & 613 & & \\
\hline Plot size $\left(\mathrm{m}^{2}\right)$ & 300 & & & 625 & & \\
\hline Average DBH $(\mathrm{cm})$ & 11.81 & 11.87 & 8.91 & 11.14 & 11.23 & 8.23 \\
\hline Average height (m) & 9.80 & 9.82 & 9.00 & 8.13 & 8.15 & 7.49 \\
\hline Density (Trees/ha) & 3,333 & 3,267 & 67 & 2,224 & 2,160 & 64 \\
\hline Basal area $\left(\mathrm{m}^{2} / \mathrm{ha}\right)$ & 41.02 & 40.60 & 0.42 & 29.18 & 28.82 & 0.36 \\
\hline
\end{tabular}

Table 2 Summary of sample trees

\begin{tabular}{ccccc}
\hline Plot & No. & Crown class & DBH $(\mathrm{cm})$ & Height $(\mathrm{m})$ \\
\hline 5 & Tree 1 & Codominant & 15.80 & 10.2 \\
& Tree 2 & Intermediate & 12.40 & 8.2 \\
& Tree 3 & Intermediate & 9.40 & 8.9 \\
& Tree 4 & Suppressed & 7.10 & 7.0 \\
\hline 3 & Tree 5 & Suppressed & 6.11 & 6.6 \\
& Tree 6 & Intermediate & 8.55 & 8.6 \\
& Tree 7 & Intermediate & 11.30 & 10.6 \\
& Tree 8 & Codominant & 14.07 & 12.3 \\
& Tree 9 & Dominant & 17.06 & 13.8 \\
\hline
\end{tabular}

$2 \sigma$ ) from or to it. In Plot 3 , we arranged the measured DBH in ascending order, categorized the values into 5 groups, and calculated the mean in each group. We chose mizunara oak with the mean from each group. We felled one dominant, one co-dominant, two intermediate and one suppressed tree in Plot 3 ; and one co-dominant, two intermediate and one suppressed tree in Plot 5. In Plot 3, there was no dominant tree that was accessible for a tractor. Table 2 shows a summary of the selected trees.

Selected mizunara oaks were felled leaving a $0.3 \mathrm{~m}$-high stump. Tree height, diameter at $0.3 \mathrm{~m}$, that is, diameter at stump height (DSH), bole height and crown were measured. The north site of each tree was marked at the ground level. Trees were separated into stem, branch and foliage and their fresh weight were measured using spring balances according to each stratum, i.e., $0.3,1.3,3.3$ and then every $2 \mathrm{~m}$. If the last stratum was less than 3 meters, it was cut to the closest 1meter last of all. Disc of stem in each stratum was cut at the bottom per stratum. Then, a sample of stem, branch, and foliage of each stratum was taken for further processing in the laboratory.

We excavated the four sample trees of mizunara oak with a power tractor in Plot 5. On the other hand, we excavated the five sample trees in Plot 3 with tools by hand tool. Then, the root systems were brought to the laboratory where they were washed to remove soil particles and exposed to the open air to dry. All soil was removed from the root plate with a high- pressure jet water stream, and the stem was cut from the root plate at the root collar. Nevertheless fresh weights of roots with a diameter $>5.0 \mathrm{~cm}$ for Trees 7,8 , and 9 were measured in the field without washing them, as they were too heavy to be brought to the nearest road.

Subsequently, root systems were placed upside down on a flat surface desk for measurement processing. We weighed the root biomass and recorded the root length and diameter of root cross-sectional area at both ends according to diameter classes of $<0.2 \mathrm{~cm}, 0.2-0.5 \mathrm{~cm}, 0.5-2.0 \mathrm{~cm}, 2.0-5.0 \mathrm{~cm}$ and $>5.0 \mathrm{~cm}$, at precisions of $1.0 \mathrm{~g}$ and $1 \mathrm{~cm}$, respectively. The length of roots with a diameter under $0.2 \mathrm{~cm}$ was not measured, as they were fragile and their branches were difficult to spread out. Many roots were broken during excavation and remained in the soil. The diameters of broken root ends were measured outside the bark in two perpendicular directions for Trees 1 to 4 in Plot 5 and Tree 5 in Plot 3.

Data Analysis

\section{Measurement of samples}

Stem analysis consisted of counting of annual rings and measuring of diameter on stem cross sections lying at each stratum. The annual rings were measured from centre to outside the bark at one-year intervals across the radius in four directions and perpendicular to each other. Stem volume was calculated from measured data. 
Samples of foliage were dried at temperature of $96^{\circ} \mathrm{C}$ for 48 hours. Samples from roots of different diameter classes together with samples from stem and branch were dried to a constant weight at a temperature of $105^{\circ} \mathrm{C}$ to determine conversion factors from fresh weight to dry weight.

\section{Estimation of root variables}

The diameter at the broken ends was tallied and a regression equation was applied to correct these losses of roots. To create the regression equation to determine missing roots, first of all cross-sectional diameters and length of unbroken root ends were sampled and measured on each root branching or every $25 \mathrm{~cm}$ if a distance between branches was greater than $25 \mathrm{~cm}$. Second, root volume, biomass and area were calculated. As the sample of unbroken end of roots was weighed in total, the fraction of biomass was calculated by employing the ratio of root volume. Third, they were summed according to the branching in order to determine the proportion of loss of roots. Finally, regression equations of cross-sectional diameters of unbroken root ends versus root biomass, volume, area and length were developed for root diameter classes $0.2-0.5 \mathrm{~cm}$ and $0.5-2.0 \mathrm{~cm}$ and for total root systems. The frustum of cone formulae used to calculate root area and volume were as follows:

$$
\begin{aligned}
& \text { Root area }=\frac{\pi}{2}\left(d_{1}+d_{2}\right) \sqrt{\left(\frac{d_{1}-d_{2}}{2}\right)^{2}+l^{2}}, \\
& \text { Root volume }=\frac{\pi}{12} l\left(d_{1}^{2}+d_{1} d_{2}+d_{2}^{2}\right),
\end{aligned}
$$

where $d_{1}$ and $d_{2}$ were diameters of section and $l$ was length. Only regression equations for roots with a diameter of 0.2 . $0.5 \mathrm{~cm}$ and $0.5-2.0 \mathrm{~cm}$ were developed because roots with a diameter under $0.2 \mathrm{~cm}$ were fragile and their branches were difficult to spread out.

\section{Allometric equations with regard to roots}

Allometric equations of root biomass, volume, area and length versus other tree variables were developed for the two root diameter classes and for the total root system, in order to predict root systems from other tree variables such as DBH. In the equations, the tree variables were used as the independent variable $x$ in a simple regression of the root system as dependent variable $y$ (DREXHAGE and COLIN, 2001; CANADELL and RODA, 1991):

$$
y=a x^{b},
$$

where $a$ and $b$ were parameters. The parameters were estimated separately from roots investigated in Plot 5 and Plot 3 using a logarithmic transformation of Eq. (3), because they were located in a different stand and excavated in different ways. Regression equations of root biomass versus other tree variables were developed to estimate root stand biomass for each plot.

\section{RESULTS}

\section{Measured Root Systems}

The results of measured root systems are described in Fig. 2. Root diameter classes $<0.2,0.2-0.5,0.5-2.0,2.0-5.0$, and $>5.0 \mathrm{~cm}$ were named root classes $1,2,3,4$, and 5 , respectively.

Root class 5 formed about three fifths of the root biomass and the other classes two fifths. Root class 5 in Plot 3 (67\%) accounted for a higher percentage of root biomass than that in Plot 5 (53\%). Otherwise, root class 3 in Plot 3 (14\%) contributed a smaller percentage of root biomass than that in Plot 5 (22\%). Root class 2 distributed roughly $14 \%$ for all trees excluding Tree 1 . Tree 4 had the smallest percentage of root class $5(43 \%)$ but it had the highest percentage of root class 3 (29\%). Root class 5 in Trees 5, 7, 8 and 9 contributed about $69 \%$ of root biomass in Plot 3. Although root class 5 in Tree 6 had lowest percentage of root biomass (59\%), root class 3 had the highest percentage of root biomass $(19 \%)$ among the trees in Plot 3. Trees 2 and 3 in Plot 5 accounted for a similar percentage of biomass in each root diameter class.

Root classes 5, 4, 3, 2 and 1 roughly accounted for 1.5, 4.3, 34.8 , and $59.3 \%$ of the root length. The root length percentage of root class 3 in Plot $3(36.3 \%)$ was greater than that in Plot 5 (33.0\%). By contrast, the root length percentage of root class 2 in Plot $3(57.2 \%)$ was smaller than that in Plot $5(61.8 \%)$. Root class 2 represented as much as $59.3 \%$ of the total root length, although only $3.6 \%$ of the root biomass. On the other hand, root class 5 constituted as much as $61.0 \%$ of the root biomass, and only $1.5 \%$ of their total length.

The root area percentage of root class 4 (15.9) and 5 (16.2) in Plot 3 was greater than that in Plot 5 (13.5 and 13.6 in that order). By contrast, the root area percentage of root class 2 (42.6) and root class 3 (25.2) in Plot 3 was smaller than that (45.5 and 27.3, respectively) in Plot 5 . Root class 3 contributed the highest portion of root area $(43.9 \%)$. Then, root classes 2 , 4 , and 5 constituted $26.2 \%, 15.1 \%$, and $14.9 \%$, respectively. Although Trees 2 to 6 might have a similar percentage of root area, other trees might create a different root class pattern. Root class 2 represented $26.2 \%$ of the root area, but as much as $59.3 \%$ of the total root length. On the other hand, root class 3 constituted as much as $43.9 \%$ of the root area, and $34.8 \%$ of the total root length. Furthermore, root class 5 constituted as much as $61.0 \%$ of the root biomass, and only $14.9 \%$ of the total root area.

Tree 1 gave the highest value of root volume, unlike the other root variables for which Tree 9 always dominated other sample trees. As did root biomass $(61.0 \%)$, root class 5 dominated the percentage of root volume (55.4\%). Root class 5 represented $55.4 \%$ of the root volume, but as much as $1.5 \%$ of 
a. Root biomass
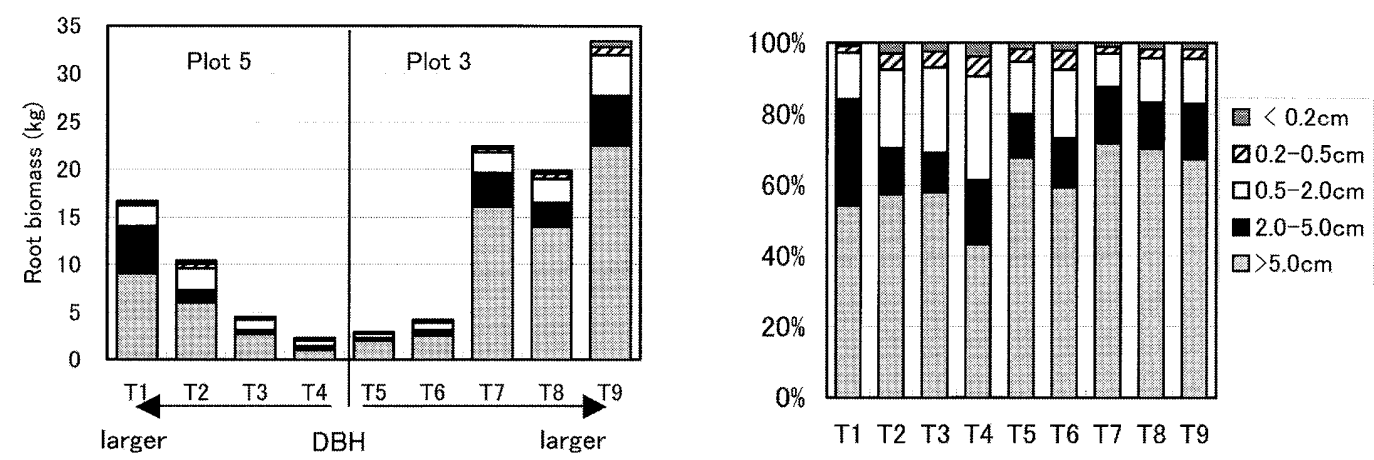

b. Root length
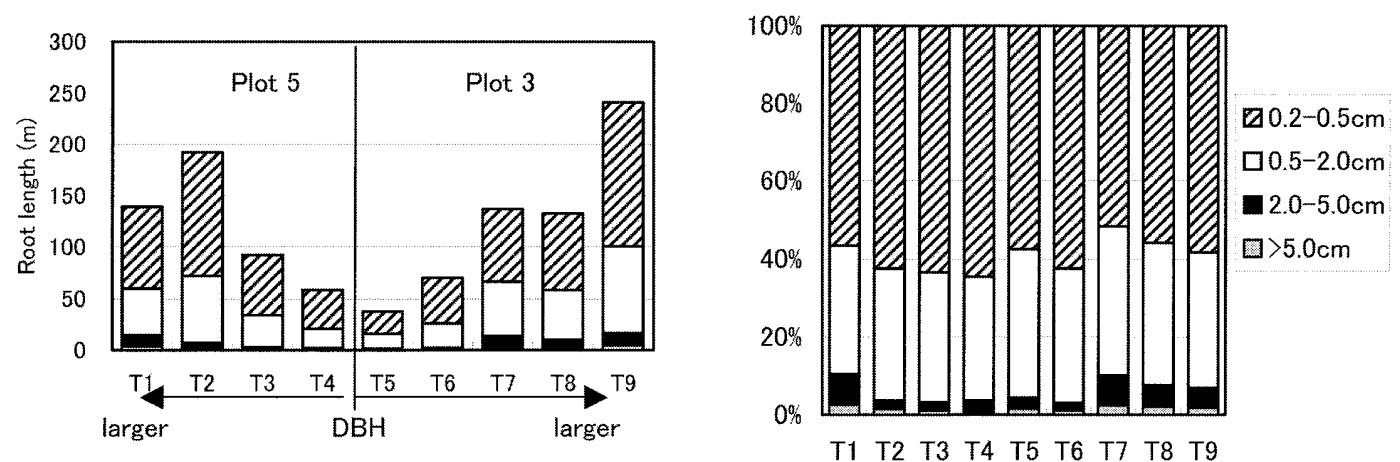

c. Root area
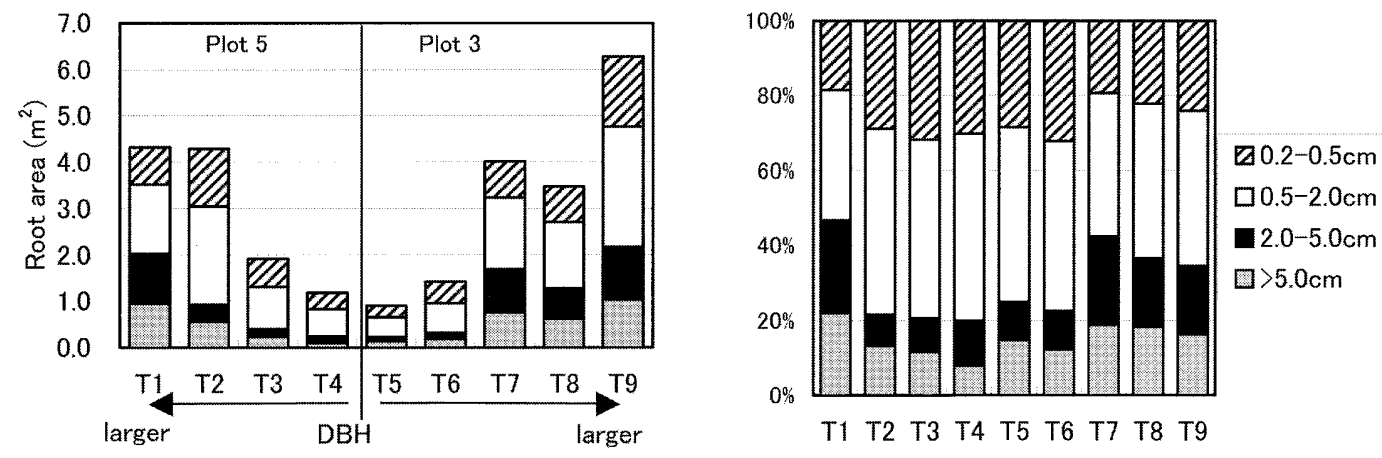

d. Root volume
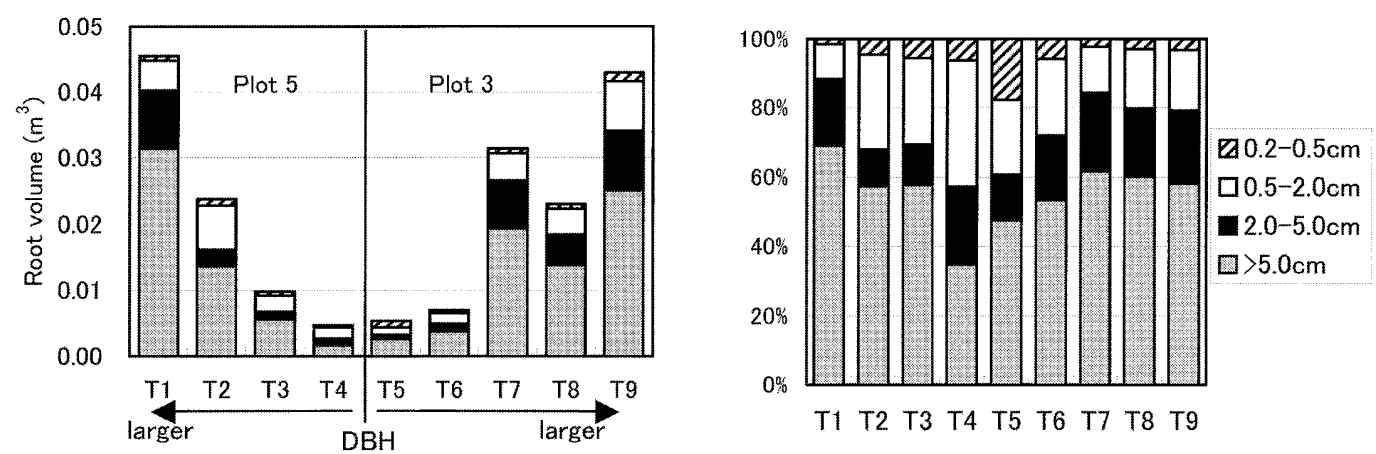

Fig. 2 Root variables and their percentage by root diameter classes 
the total root length and $14.9 \%$ of the total root area. On the other hand, root class 2 constituted as much as $59.3 \%$ of the root length, and only $5.6 \%$ of the total root volume. In general, the percentage distributions of root biomass and root volume were quite similar.

\section{Missing Roots}

The coefficient of determination of regression equations by power function for root biomass, volume, length or area and root diameter by root diameter classes or for total root system are shown in Table 3 . Although the correlation for root biomass and root class 2 was 0.13 , that for root biomass and root class 3 was 0.77 in Plot 5 . On the other hand, the correlation for both root diameter classes in Plot 3 had a value of about 0.50 . The same applied to root area where root class 3 had a better correlation than the other root classes. Also, the correlation for both root diameter classes in Plot 3 had a value of about 0.37 . By contrast, root length had a low correlation for both root classes in both plots $\left(\mathrm{R}^{2}<0.37\right)$. In general, root class 3 had a much higher coefficient correlation than root class 2 in Plot 5, but was only slightly different in Plot 3 . Regression equations by power function for the total root system are also shown in Table 3. While root biomass, volume and area were highly correlated with root diameter, root length had the lowest correlation $\left(\mathrm{R}^{2}<0.64\right)$. In general, missing roots in Plot 5 had a higher correlation coefficient with root diameter than that in Plot 3. The parameters of regression equations by

Table 3 Correlation between missing root system variables and root diameter by root diameter classes and for total root system

\begin{tabular}{|c|c|c|c|c|c|}
\hline \multirow[b]{2}{*}{ Root system } & \multirow[b]{2}{*}{ Root class } & \multicolumn{2}{|c|}{ Plot 5} & \multicolumn{2}{|c|}{ Plot 3} \\
\hline & & No. of samples & $\mathrm{R}^{2}$ & No. of samples & $\mathrm{R}^{2}$ \\
\hline \multirow{3}{*}{ Root biomass } & 2 & 10 & 0.135 & 162 & $0.546^{* *}$ \\
\hline & 3 & 23 & $0.779^{* *}$ & 91 & $0.501^{* *}$ \\
\hline & Total & 40 & $0.914^{* *}$ & 255 & $0.823^{* *}$ \\
\hline \multirow{3}{*}{ Root volume } & 2 & 10 & 0.135 & 162 & $0.597^{* *}$ \\
\hline & 3 & 23 & $0.779^{* *}$ & 91 & $0.501^{* *}$ \\
\hline & Total & 40 & $0.914^{* *}$ & 255 & $0.841^{* *}$ \\
\hline \multirow{3}{*}{ Root area } & 2 & 10 & 0.000 & 162 & $0.386^{* *}$ \\
\hline & 3 & 23 & $0.631^{* *}$ & 91 & $0.360^{* *}$ \\
\hline & Total & 40 & $0.836^{* *}$ & 255 & $0.748^{* *}$ \\
\hline \multirow{3}{*}{ Root length } & 2 & 10 & 0.116 & 162 & $0.136^{* *}$ \\
\hline & 3 & 23 & $0.366^{* *}$ & 91 & $0.263^{* *}$ \\
\hline & Total & 40 & $0.644^{* *}$ & 255 & $0.593^{* *}$ \\
\hline
\end{tabular}

*, significant (at $5 \%$ level); ${ }^{* *}$, highly significant (at $1 \%$ level)

Table 4 The parameters of regression equations between total missing root system variables and root diameter

\begin{tabular}{crrrrr}
\hline & \multicolumn{2}{c}{ Plot 5} & & \multicolumn{2}{c}{ Plot 3 } \\
\cline { 2 - 3 } \cline { 5 - 6 } & \multicolumn{1}{c}{$a$} & \multicolumn{1}{c}{$b$} & & \multicolumn{1}{c}{$a$} & $b$ \\
\hline Root biomass $(\mathrm{g})$ & 0.0360 & 2.3681 & & 0.0238 & 2.5727 \\
Root volume $\left(\mathrm{mm}^{3}\right)$ & 79.7902 & 2.3681 & & 47.3459 & 2.6184 \\
Root area $\left(\mathrm{mm}^{2}\right)$ & 242.0080 & 1.6715 & & 171.8005 & 1.9094 \\
Root length $(\mathrm{mm})$ & 45.4515 & 1.1531 & & 42.2094 & 1.3874 \\
\hline
\end{tabular}

Table 5 Estimated missing root biomass, volume, length and area in each sample tree

\begin{tabular}{|c|c|c|c|c|c|c|c|c|c|c|}
\hline & & \multicolumn{4}{|c|}{ Plot 5 (digging by tractor) } & \multicolumn{5}{|c|}{ Plot 3 (digging by hand tool) } \\
\hline & & Tree 1 & Tree 2 & Tree 3 & Tree 4 & Tree 5 & Tree 6 & Tree 7 & Tree 8 & Tree 9 \\
\hline Root biomass & Missing & 0.33 & 0.19 & 0.09 & 0.10 & 0.04 & 0.05 & 0.29 & 0.26 & 0.44 \\
\hline$(\mathrm{kg})$ & Measured & 16.66 & 10.39 & 4.54 & 2.27 & 2.83 & 4.19 & 22.41 & 19.87 & 33.39 \\
\hline Root volume & Missing & $7.3 \times 10^{4}$ & $4.2 \times 10^{4}$ & $2.1 \times 10^{4}$ & $2.1 \times 10^{4}$ & $7.9 \times 10^{-5}$ & $1.0 \times 10^{-4}$ & $4.6 \times 10^{4}$ & $3.4 \times 10^{-4}$ & $6.3 \times 10^{-4}$ \\
\hline$\left(\mathrm{m}^{3}\right)$ & Measured & 0.0455 & 0.0238 & 0.0097 & 0.0047 & 0.0054 & 0.0069 & 0.0314 & 0.0230 & 0.0430 \\
\hline Root length & Missing & 21.07 & 11.72 & 9.39 & 8.14 & 9.05 & 17.03 & 33.38 & 32.19 & 58.68 \\
\hline (m) & Measured & 138.85 & 192.06 & 92.24 & 58.62 & 37.15 & 69.89 & 136.98 & 132.10 & 240.81 \\
\hline Root area & Missing & 0.39 & 0.22 & 0.14 & 0.14 & 0.09 & 0.15 & 0.42 & 0.36 & 0.66 \\
\hline$\left(\mathrm{m}^{2}\right)$ & Measured & 4.33 & 4.28 & 1.91 & 1.19 & 0.91 & 1.55 & 4.39 & 3.81 & 6.88 \\
\hline
\end{tabular}


power function between total missing roots and root diameter are shown in Table 4 . In general, parameter $a$ in Plot 5 was greater than that in Plot 3 , but parameter $b$ was smaller in Plot 5 than in Plot 3.

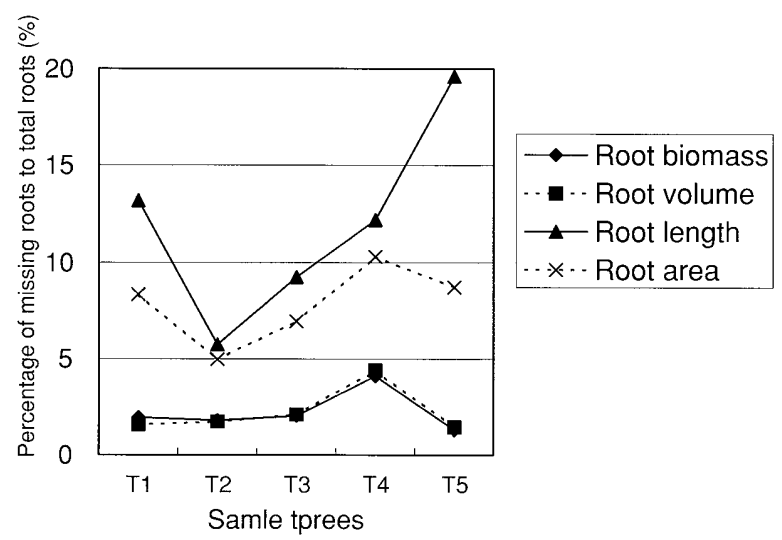

Fig. 3 Percentage of missing root biomass, volume, length and area
Estimated missing roots and their percentages are shown in Table 5 and Fig. 3, respectively. Missing broken root ends were not measured in Trees $6,7,8$, and 9 , so they were assumed to hold the same missing root percentage as Tree 5 in Plot 3 because the larger tree size such as DBH, the larger missing root part and the missing root percentage was relatively constant for Trees 1 to 4 in Plot 5. The missing percentage for root volume and biomass was approximately similar. The percentage of missing root biomass was quite low compared to measured roots. Digging roots with tools by hand resulted in a smaller loss of roots than that by tractor for root biomass and volume, comparing Tree 4 with Tree 5 . Percentage of missing root length and area were much larger than those of root biomass and volume.

Allometric Equations between Root Variables and Other Tree Variables

\section{By root diameter class}

The relationships between root system and tree variables were analyzed by power function. The length of roots with a

Table 6 Coefficients of determination of regression equations for root variables and tree variables by root diameter classes

\begin{tabular}{|c|c|c|c|c|c|c|c|c|c|c|c|}
\hline \multirow{3}{*}{ Tree variable } & \multirow{3}{*}{$\begin{array}{c}\text { Root } \\
\text { variable }\end{array}$} & \multicolumn{5}{|c|}{ Plot 5} & \multicolumn{5}{|c|}{ Plot 3} \\
\hline & & Class1 & Class2 & Class3 & Class 4 & Class 5 & Class1 & Class2 & Class3 & Class4 & Class5 \\
\hline & & $<0.2$ & $0.2-0.5$ & $0.5-2.0$ & $2.0-5.0$ & $>5.0$ & $<0.2$ & $0.2-0.5$ & $0.5-2.0$ & $2.0-5.0$ & $>5.0$ \\
\hline \multirow{3}{*}{$\mathrm{DBH}(\mathrm{cm})$} & Biomass & 0.421 & 0.699 & 0.899 & $0.905^{*}$ & $0.981^{* *}$ & $0.975^{* *}$ & $0.988^{* *}$ & $0.977^{* *}$ & $0.885^{*}$ & $0.870^{*}$ \\
\hline & Length & & 0.631 & 0.710 & 0.937 & $0.967^{*}$ & & $0.958^{* *}$ & $0.945^{* *}$ & $0.832^{*}$ & $0.869^{*}$ \\
\hline & Area & & 0.636 & 0.732 & 0.901 & $0.994^{* *}$ & & $0.950^{* *}$ & $0.940^{* *}$ & $0.853^{*}$ & $0.872^{*}$ \\
\hline \multirow{3}{*}{$\mathrm{DSH}(\mathrm{cm})$} & Biomass & 0.413 & 0.728 & 0.899 & 0.779 & $0.985^{* *}$ & $0.982^{* *}$ & $0.967^{* *}$ & $0.984^{* *}$ & $0.921^{* *}$ & $0.919^{*}$ \\
\hline & Length & & 0.671 & 0.747 & 0.828 & $0.915^{*}$ & & $0.930^{* *}$ & $0.947^{* *}$ & $0.887^{*}$ & $0.912^{*}$ \\
\hline & Area & & 0.691 & 0.744 & 0.776 & $0.968^{*}$ & & $0.923^{* *}$ & $0.946^{* *}$ & $0.899^{*}$ & $0.915^{*}$ \\
\hline \multirow{3}{*}{ Leaf area $\left(m^{2}\right)$} & Biomass & 0.548 & 0.846 & $0.907^{*}$ & 0.546 & $0.915^{*}$ & $0.955^{* *}$ & $0.910^{*}$ & $0.933^{* *}$ & $0.846^{*}$ & $0.868^{*}$ \\
\hline & Length & & 0.820 & 0.867 & 0.604 & 0.825 & & $0.863^{*}$ & $0.875^{*}$ & $0.813^{*}$ & $0.869^{*}$ \\
\hline & Area & & 0.849 & 0.838 & 0.538 & 0.866 & & $0.869^{*}$ & $0.892^{*}$ & $0.818^{*}$ & $0.859^{*}$ \\
\hline \multirow{3}{*}{ Volume $\left(\mathrm{m}^{3}\right)$} & Biomass & 0.408 & 0.706 & 0.899 & 0.858 & $0.989^{* *}$ & $0.936^{* *}$ & $0.983^{* *}$ & $0.943^{* *}$ & $0.825^{*}$ & $0.802^{*}$ \\
\hline & Length & & 0.642 & 0.721 & 0.898 & $0.947^{*}$ & & $0.947^{* *}$ & $0.908^{*}$ & 0.763 & $0.800^{*}$ \\
\hline & Area & & 0.654 & 0.732 & 0.854 & $0.989^{* *}$ & & $0.929^{* *}$ & $0.894^{*}$ & $0.788^{*}$ & $0.805^{*}$ \\
\hline \multirow{3}{*}{$\begin{array}{c}\text { Stem } \\
\text { biomass(kg) }\end{array}$} & Biomass & 0.383 & 0.684 & 0.883 & 0.861 & $0.983^{* *}$ & $0.969^{* *}$ & $0.997^{* *}$ & $0.977^{* *}$ & $0.886^{*}$ & $0.859^{*}$ \\
\hline & Length & & 0.619 & 0.700 & 0.901 & $0.937^{*}$ & & $0.977^{* *}$ & $0.956^{* *}$ & $0.826^{*}$ & $0.860^{*}$ \\
\hline & Area & & 0.632 & 0.710 & 0.859 & $0.983^{* *}$ & & $0.967^{* *}$ & $0.945^{* *}$ & $0.852^{*}$ & $0.865^{*}$ \\
\hline \multirow{3}{*}{$\begin{array}{c}\text { Branch } \\
\text { biomass(kg) }\end{array}$} & Biomass & 0.351 & 0.633 & 0.851 & $0.922^{*}$ & $0.962^{*}$ & $0.857^{*}$ & $0.849^{*}$ & $0.844^{*}$ & 0.731 & 0.759 \\
\hline & Length & & 0.562 & 0.645 & $0.952^{*}$ & $0.938^{*}$ & & 0.763 & 0.761 & 0.705 & 0.744 \\
\hline & Area & & 0.568 & 0.666 & $0.921^{*}$ & $0.977^{*}$ & & 0.745 & 0.764 & 0.706 & 0.740 \\
\hline \multirow{3}{*}{$\begin{array}{c}\text { Foliage } \\
\text { biomass(kg) }\end{array}$} & Biomass & 0.334 & 0.657 & 0.751 & 0.466 & 0.827 & $0.950^{* *}$ & 0.893 & $0.922^{* *}$ & $0.839^{*}$ & $0.865^{*}$ \\
\hline & Length & & 0.632 & 0.687 & 0.529 & 0.683 & & $0.849^{*}$ & $0.864^{*}$ & $0.808^{*}$ & $0.869^{*}$ \\
\hline & Area & & 0.674 & 0.643 & 0.466 & 0.766 & & $0.859^{*}$ & $0.886^{*}$ & $0.811^{*}$ & $0.856^{*}$ \\
\hline \multirow{3}{*}{$\begin{array}{l}\text { Aboveground } \\
\text { biomass (kg) }\end{array}$} & Biomass & 0.377 & 0.678 & 0.879 & 0.862 & 0.982 & $0.968^{* *}$ & $0.989^{* *}$ & $0.972^{* *}$ & $0.875^{*}$ & $0.858^{*}$ \\
\hline & Length & & 0.613 & 0.694 & 0.902 & $0.934^{*}$ & & $0.958^{* *}$ & $0.940^{* *}$ & $0.821^{*}$ & $0.857^{*}$ \\
\hline & Area & & 0.626 & 0.704 & 0.860 & $0.982^{* *}$ & & $0.947^{* *}$ & $0.932^{* *}$ & $0.843^{*}$ & $0.860^{*}$ \\
\hline
\end{tabular}


diameter under $0.2 \mathrm{~cm}$ was not measured, as they were fragile and their branches were difficult to spread out. Coefficients of determination of root biomass, length and area versus tree variables by root diameter classes are shown in Table 6 .

In general, the greater the root diameter, the greater was the coefficient correlation for Plot 5 , but in Plot 3 it was the opposite. A high correlation $\left(\mathrm{R}^{2}>0.85\right)$ was recorded between root biomass and other tree variables for root class 1 in Plot 3 , but there was a low correlation $\left(\mathrm{R}^{2}<0.55\right)$ in Plot 5 . A statistically significant correlation (average of $\mathrm{R}^{2}=0.90$ for Plot 5 and 0.85 for Plot 3 ) existed in root biomass, length or area and other tree variables. Also, a relatively close correlation was seen between root biomass, length or area and other tree variables for each root class in both plots.

In Plot 5, regression of DBH versus root biomass, length and area for root class 5 had the highest correlation with $\mathrm{R}^{2}$ of $0.98,0.96$, and 0.99 , respectively, followed by $0.70,0.63$ and 0.64 , respectively, for root class 2 . On the other hand, $\mathrm{R}^{2}$ was 0.99, 0.96 and 0.95, respectively, for root class 2 in Plot 3 , but only $\mathrm{R}^{2}$ of about 0.87 was obtained with all the three root variables for root class 5. Furthermore, coefficients of determination between root biomass and DBH for root class 1 in Plots 5 and 3 were 0.42 and 0.94 , respectively.

The DSH-root biomass correlation was comparable to DBH-root biomass correlation. A similar correlation also existed between DBH and DSH in terms of root length and area. A statistically significant correlation $\left(\mathrm{R}^{2}>0.81\right)$ existed between root biomass, length or area and leaf area in Plot 3 . A high correlation $\left(\mathrm{R}^{2}>0.84\right)$ was found in root biomass, length or area and height in Plot 3 , but there was a low correlation $\left(\mathrm{R}^{2}\right.$
$<0.70)$ in Plot 5.

The greater the root diameter, the greater was the coefficient correlation of root biomass, length and area versus aboveground biomass, stem, branch and foliage in Plot 5 , but it was the opposite in Plot 3.

\section{For total root system}

Correlations of root variables versus tree variables for total root system are shown in Table 7 . Coefficients of determination of DBH with root biomass, length, area and volume in Plot 5 were $0.99,0.78,0.93$ and 1.00, respectively, and $0.90,0.96,0.92$ and 0.86 , respectively, in Plot 3 . In other words, the correlation between $\mathrm{DBH}$ and root length was lower in Plot 5 than in Plot 3. Correlation of DSH with root biomass, length, area or volume had coefficients comparable to those for the correlation to DBH.

Stem biomass and aboveground biomass were relatively closely correlated to root biomass, length, area and volume with $\mathrm{R}^{2}$ of $0.98,0.76,0.90$ and 0.98 , respectively, in Plot 5 and 0,89, 0.96, 0.92 and 0.84, respectively, in Plot 3. Approximately linear correlations were seen between stem biomass or aboveground biomass and root biomass in both plots. A high correlation $\left(R^{2}=0.89\right)$ was found between branch biomass and root system in Plot 5, but the correlation was relatively low $\left(\mathrm{R}^{2}\right.$ $=0.75)$ in Plot 3 . On the other hand, the correlation between foliage biomass and root system was relatively low $\left(R^{2}=0.72\right)$ in Plot 5 , but as high as 0.86 in Plot 3.

Table 7 Coefficients of determination of regression equations for root variables and tree variables for total root system

\begin{tabular}{|c|c|c|c|c|c|c|c|}
\hline $\begin{array}{c}\text { Tree } \\
\text { variables }\end{array}$ & $\begin{array}{c}\text { Root } \\
\text { variables }\end{array}$ & Plot 5 & Plot 3 & $\begin{array}{c}\text { Tree } \\
\text { variables }\end{array}$ & $\begin{array}{c}\text { Root } \\
\text { variables }\end{array}$ & Plot 5 & Plot 3 \\
\hline DBH & Biomass & $0.994^{* *}$ & $0.897^{*}$ & $\mathrm{DBH}$ & Biomass & $0.958^{*}$ & $0.937^{* *}$ \\
\hline \multirow[t]{3}{*}{$(\mathrm{cm})$} & Length & 0.777 & $0.956^{* *}$ & $(\mathrm{~cm})$ & Length & 0.795 & $0.946^{* *}$ \\
\hline & Area & $0.931^{*}$ & $0.923^{* *}$ & & Area & $0.902^{*}$ & $0.940^{* *}$ \\
\hline & Volume & $0.998^{* *}$ & $0.855^{*}$ & & Volume & $0.950^{*}$ & $0.893^{*}$ \\
\hline Volume & Biomass & $0.984^{* *}$ & $0.836^{*}$ & Leaf area & Biomass & 0.848 & $0.880^{*}$ \\
\hline \multirow[t]{3}{*}{$\left(\mathrm{m}^{3}\right)$} & Length & 0.781 & $0.929^{* *}$ & $\left(m^{3}\right)$ & Length & 0.877 & $0.873^{*}$ \\
\hline & Area & $0.919^{*}$ & $0.878^{*}$ & & Area & 0.867 & $0.874^{*}$ \\
\hline & Volume & $0.984^{* * *}$ & $0.786^{*}$ & & Volume & 0.813 & $0.832^{*}$ \\
\hline Stem & Biomass & $0.979^{*}$ & $0.890^{*}$ & Branch & Biomass & $0.978^{*}$ & $0.773^{*}$ \\
\hline biomass & Length & 0.760 & $0.970^{* *}$ & biomass & Length & 0.715 & 0.766 \\
\hline & Area & $0.905^{*}$ & $0.928^{* *}$ & (kg) & Area & 0.890 & 0.750 \\
\hline & Volume & $0.980^{*}$ & $0.854^{*}$ & & Volume & $0.989^{* *}$ & 0.696 \\
\hline Foliage & Biomass & 0.742 & $0.875^{*}$ & Above & Biomass & $0.977^{*}$ & $0.886^{*}$ \\
\hline biomass & Length & 0.695 & $0.860^{*}$ & ground & Length & 0.755 & $0.952^{* * *}$ \\
\hline \multirow[t]{2}{*}{ (kg) } & Area & 0.709 & $0.867^{*}$ & biomass & Area & 0.901 & $0.915^{*}$ \\
\hline & Volume & 0.717 & $0.830^{*}$ & (kg) & Volume & $0.980^{*}$ & $0.843^{*}$ \\
\hline
\end{tabular}

${ }^{*}$, for significant (at $5 \%$ level) $;{ }^{* *}$, for highly significant (at $1 \%$ level) 


\section{DISCUSSION}

Part of the root system was lost during the excavation the root systems of the sampled mizunara oak trees. The fit of the regression is highly dependent on the root extraction technique (DREXHAGE and COLIN, 2001). Root system equations established from samples of seemingly unbroken root ends might allow the estimation of missing parts of the root systems. The regression equations by power function for the entire root system were applied to determine the missing root parts because of the high correlation, while the regression equations between root diameter classes and root system variables had lower correlation (Table 3). Missing root parts represented between 1 and $5 \%$ of the measured root biomass. LE GofF and OtToRini (2001) estimated that missing roots of beech represented between 10 to $20 \%$ of the measured value, where regression equation for estimating root class 1 was included. However, the biomass of missing fine roots should represent a very small part of the total root system biomass (LE GofF and OtToRini, 2001). The estimation of the biomass of missing root parts appears essential when the root system is excavated by hand (LE GOFF and OTTORINI, 2001). The greater the root diameter, the greater was the coefficient of determination in Plot 5, but it was the opposite in Plot 3, probably because the plots were located in different sites. In addition, in root class 5, fresh weight for Trees 7, 8 and 9 was measured in the field without washing them and errors might have increased due to the sticky soil.

The few works available showed data on the relationship between quantity of roots within different diameter groups and aboveground tree variables. The root biomass distribution patterns show that the larger tree had a relatively higher proportion of root class 5 (Fig. 2). This might be related to mechanical constraints, which impose a relatively greater development of structural roots in a larger tree to ensure their stability and anchorage in the soil (STOKES, 1997 in LE GOFF and OTTORINI, 2001). Relating with DBH, the aboveground biomass and root systems showed higher correlations with increasing root diameter class on a logarithmic scale in Plot 5 as shown in Table 6. This might be due to the morphology of the root system which makes up several levels of "hierarchy" starting from the stump-primary ones, secondary ones, tertiary ones, and so on (KONOPKA and TSUKAHARA, 2000).

As tree $\mathrm{DBH}$ decreased, the root length per dry weight (Fig. 4) and root area per dry weight tended to increase in each plot. We found that root length and root area per unit root weight for root diameter $0.2-0.5 \mathrm{~cm}$ was higher in Plot 5 (27 $\left.\mathrm{cm} / \mathrm{g}, 27 \mathrm{~cm}^{2} / \mathrm{g}\right)$ than in Plot $3\left(18 \mathrm{~cm} / \mathrm{g}, 20 \mathrm{~cm}^{2} / \mathrm{g}\right)$. Roots at a site with a low site index are longer than those at a site with a high site index and the surface of root systems is higher in dry soil than in moist soil (KARIZUMI, 1974b), i.e., Plot 5 has a smaller site index and drier soil than Plot 3 . However, the dry weight ratio for root diameter $<0.5 \mathrm{~cm}$ was lower in Plot 5 than

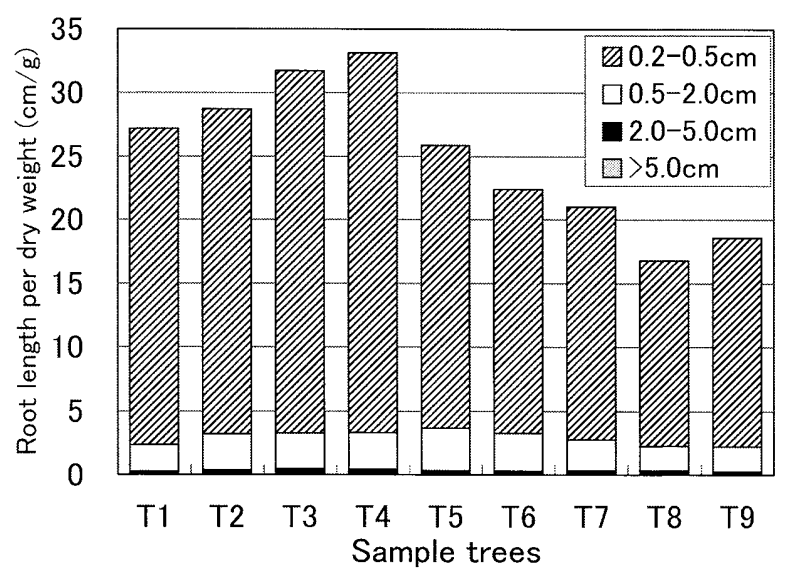

Fig. 4 Root length per dry weight by root diameter classes for each sample tree

in Plot 3 ( 0.5 and 0.7 , respectively). This contradicts with the argument for the root length and root area per unit dry weight, as a higher root dry weight ratio is expected. Generally, the stand soil with a small site index is either dry or heavily wet (KARIZUMI, 1974b).

The possibility of estimating below-stump biomass by using an easily obtainable above-stump parameter such as DBH has already been tried for various tree species (SANTANTONIA, 1977). Allometric equations are useful for estimating plant biomass by component in forest (SANTANTONIA, 1990 in DREXHAGE and CoLIN, 2001). Tree DBH proved to be a good predictor of root systems for different root category and for the entire root system of mizunara-oak in the condition of the experimental stand. This is consistent with already published results on oak species and other species (DREXHAGE et al., 1999; Le GofF and OTTORINI, 2001; DreXHAGE and Colin, 2001). This research also reconfirmed that the relationship between root biomass and DBH is generally best fitted by a power function (DreXhage and Colin, 2001; CANADELl and RoDA, 1991). The regression equations developed might be useful for estimating root systems from DBH, which is a simple variable to measure. Furthermore, for applications in forestry inventories and as an input variable for entire treegrowth models and carbon storage allocation, the equations might be extremely useful for a simple estimation of root systems without the need to extract them. However, DSH might be a useful estimator as it also has a high correlation to root systems if branching starts at breast height (CANADELL $e t$ $a l ., 1988$; CANADEll and Roda, 1991; Thies and CunNingham, 1996). DREXHAGE and Colin (2001) suggested that researchers should need to agree on whether the stump should be considered as a part of the root system or not. Also, HofFMAN (2001) highlighted that it is necessary to uniformly define the limits of the root diameter classes and stump biomass whether it is listed separately, or ignored to be able to compare the 
Table 8 The parameters and coefficients of determination of regression equations between DBH and coarse-root weight (values in No. 1 to 5 were cited from DrEXHAGE and CoLIN, 2001)

\begin{tabular}{|c|c|c|c|c|c|}
\hline No. & Species & No of data & $a$ & $b$ & $\mathrm{R}^{2}$ \\
\hline 1 & F. sylvatica ,(PELLINEN in (DreXHAGE et al., 2001) & 8 & -2.00 & 2.70 & 0.98 \\
\hline 2 & F. sylvatica ,(Le Goff and OTTORINi, 2001) & 16 & -1.66 & 2.54 & 0.99 \\
\hline 3 & Q.petraea, (DREXHAGE and COLIN, 2001) & 71 & -1.56 & 2.44 & 0.94 \\
\hline 4 & Q.ilex, (CANADEL and RoDA, 1991) & 32 & -1.05 & 2.19 & 0.73 \\
\hline 5 & Q.douglasii, (MiLlikin et al., 1997) & 6 & -0.56 & 1.81 & 0.89 \\
\hline 6 & Q.crispula, in Plot 5 (this study) & 4 & -1.75 & 2.50 & 0.99 \\
\hline 7 & Q.crispula, in Plot 3 (this study) & 5 & -1.59 & 2.57 & 0.90 \\
\hline
\end{tabular}

results to the other researchers' ones. In addition, VOGT et al., (1998) suggested that a uniform agreement of how root biomass and production should be sampled and calculated is urgent.

The results of quantitative analysis between root biomass and DBH among broad-leaved species (cited from DREXHAGE and Colin, 2001) is shown in Table 8. Although no statistical comparisons could be made, the present results and those obtained on other broad-leaved species have relatively similar allometric relationships between $\mathrm{DBH}$ and root biomass. $\mathrm{LE}$ GOFF and OTTORINI (2001) found that total root biomass is closely linked to tree dimension, independent of tree age and site. These results suggest that individual root biomass of oak species was estimated confidently from tree DBH.

\section{CONCLUSION}

During the excavation of the root systems of the sampled mizunara oak trees some of the root system was lost. However, the root system equations established from samples of seemingly unbroken root ends might allow the estimation of missing parts of the root system. Root length and root area per unit root dry weight might be possible as a site index indicator.

Allometric equations are a useful tool for estimating the root system by component in forests. Tree DBH proved to be a relatively good predictor of root systems for different root categories and for the entire root system to estimate carbon storage and uptake by growth of tree biomass in broad-leaved secondary forests. Furthermore, for applications in forestry inventories and as an input variable for entire tree-growth models and carbon storage allocation, the equations might be extremely useful for a simple estimation of root systems without the need to extract them. DSH can be a useful estimator as it also has a high correlation to the root system if branching starts at DBH.

\section{ACKNOWLEDGEMENTS}

We are grateful to Shigeaki YaBE and Norio TANiguchi, staff at Niigata University's Sado Forest, for their help during the field survey. We wish to thank Wataru Kimura, Masahiro Yamane, Naoto SATo, Takuya IshidA, Shun-ichiro KAKUE, Lestari Munajati and Shin-ichi ITo who assisted in the field and laboratory data collection. This research was partially supported by the Ministry of Education, Science, Sports and Culture, Grant-in-Aid for Scientific Research (A) (2), 12356005.

\section{LITERATURE CITED}

BARTELINK, H.H., (1998): A model of dry matter partitioning in trees. Tree Physiology 18: 91-101

Böнm, W., (1979): Methods of studying root systems. Ecological Studies 33, Springer-Verlag, Berlin, 188 pp

BonHAM, C.D., (1989): Measurements for terrestrial vegetation. John Wiley \& Sons Inc., New York, 388 pp

Brown, S.L., Schroeder, P.E. and Kern, J.S., (1999): Spatial distribution of biomass in forests of the Eastern USA. For. Ecol. Manage. 123: $81-90$

Brown, S., Sathaye, J., Cannell, M., and KaupPI, P., (1996): Mitigation of carbon emissions to the atmosphere by forest management. Commonwealth For. Rev. 75(1): 80-91

Canadell, J., Riba, M. and Andres, P., (1988): Biomass equations for Quercus ilex L. in the Montseny Massif, Northeastern Spain. Forestry 61(2): 137-147

CANADELl, J. and Roda, F., (1991): Root biomass of Quercus ilex in a montane Mediterranean forest. Can. J. For. Res. 21: 1771-1778

Drexhage, M., Chauviére, M., Colin, F. and Nielsen, C.N.N., (1999): Development of structural root architecture and allometry of Quercus petraea. Can. J. For. Res. 29: 600-608

Drexhage, M. and Colin, F., (2001): Research note: Estimating root system biomass from breast-height diameters. Forestry $\mathbf{7 4 ( 5 )}$ : 491-497

Drexhage, M. and Gruber, F., (1999): Comparison of radial increment and volume growth in stems and roots of Quercus petraea. Plant and Soil 217: 101-110

FulTs, J.C., (2001): Evaluation of allometric equations for estimating above-ground tree biomass and stand-level $\mathrm{C}$ accumulation. http://www.atmos.anl.gov/GCEP/2001posters/Fults_Poster.pdf

Hoffmann, C.W. and Usoltsev, V.A., 2001. Modelling root biomass distribution in Pinus sylvestris forests of the Turgai Depression of Kazakhstan. For. Ecol. Manage. 149: 103-114

KaRIZUMI, N., (1974a): The mechanism and function of tree root in 
the process of forest production. I. Method of investigation and estimation of the root biomass. Bull. For. Exp. Sta. 259: 1-99

KARIZUMI, N., (1974b): The mechanism and function of tree root in the process of forest production. II. Root biomass and distribution in stands. Bull. For. Exp. Sta. 267: 1-88

Konopka, B. and Tsukahara, H., (2000): Biomass of fine and small roots in two Japanese black pine stands of different ages. J. For. Res. 5: $71-76$

Konopka, B., Tsukahara, H. and Netsu, A., (2000): Biomass distribution in 40-year-old trees of Japanese black pine. J. For. Res. 5: $163-168$

KuRZ, W.A., Beukema, S.J. and Michael, J.A., (1996): Estimation of root biomass and dynamics for the carbon budget model of the Canadian forest sector. Can. J. For. Res. 26: 1973-1979

LACOINTE, A., (2000): Carbon allocation among tree organs: A review of basic processes and representation in functional-structural tree models. Ann. For. Sci. 57: 521-533

LE Goff, N. and OTtorini, J.M., (2001): Root biomass and biomass increment in a beech (Fagus sylvatica L.) stand in North-East France. Ann. For. Sci. 58: 1-13

Miluikin, C.S. and Bledsoe, C.S., (1999): Biomass and distribution of fine and coarse roots from blue oak (Quercus douglasii) trees in the northern Sierra Nevada foothills of California. Plant and Soil 214: $27-38$
Santantonio, D., Hermann, R.K. and Overton, W.S., (1977): Root biomass studies in forest ecosystems. Pedobiologia 17: 1-31

Tatsuhara, S., Miguchi, H. and Kato, M., (2002): The stand structure and growth of a secondary mizunara oak forest. Trans. Jpn. For. Soc. 113: 442 (in Japanese)

Ter-mikaelian, M.T. and Korzukhin, M.D., (1997): Biomass equations for sixty-five North American tree species. For. Ecol. Manage. 97: 1-24

Thies, W.G. and Cunningham, P.G., (1996): Estimating large-root biomass from stump and breast-height diameters for Douglas-fir in western Oregon. Can. J. For. Res. 26: 237-243

Vogt, K.A., Vogt, D.J. and Bloomfield, J., (1998): Analysis of some direct and indirect methods for estimating root biomass and production of forests at an ecosystem level. Plant and Soil 200: 7189

Vogt, K.A., Vogt, D.J., Moore, E.E., and Sprugel, D.G., (1989): Methodological considerations in measuring biomass, production, respiration and nutrient resorption for tree roots in natural ecosystems (In ToRREY, J.G. and WINSHIP, L.J. (eds.) Applications of continuous and steady-state methods in root biology)., Kluwer Academic Publishers, Dordrecht, The Netherlands, 217-232

(Received 7 April 2003)

(Accepted 3 September 2003) 